\title{
A RAINHA FANTASIOSA ${ }^{1}$
}

\author{
Jean-Jacques Rousseau
}

- Havia outrora um rei que amava seu povo...

- Isso começa como um conto de fadas? - interrompeu o druida.

- Ele o é também - respondeu Jalamir. - Havia, portanto, um rei que amava seu povo e que, consequientemente, era adorado por ele. Ele havia empregado todos os seus esforços para encontrar ministros igualmente bem intencionados, mas, tendo reconhecido enfim a loucura de uma tal busca, ocupou-se da tarefa de fazer totalmente sozinho todas as coisas que podia subtrair à atividade nociva deles. Como estava corajosamente obstinado no bizarro projeto de tornar seus súditos felizes, ele agia de acordo, e uma conduta tão singular fazia-o passar por um ridículo inesquecível entre os nobres. 0 povo o bendizia, mas na corte ele passava por louco. Fora isto, não carecia de méritos. Chamava-se Fênix.

Se esse príncipe era extraordinário, tinha uma esposa que não o era menos. Viva, distraída, caprichosa, louca na cabeça, sábia no coração, boa por temperamento, maldosa por capricho, eis em poucas palavras o retrato da rainha. Fantasiosa era seu nome. Nome célebre, que ela havia recebido de seus ancestrais em linha feminina e do qual, portanto, mantinha dignamente a honra. Esta pessoa tão ilustre e tão sensata era o encanto e 0 suplício de seu querido esposo, pois ela o amava com grande sinceridade, talvez por causa da facilidade que tinha de atormentá-lo. Malgrado o amor recíproco que reinava entre eles, passaram muitos anos sem poder obter nenhum fruto de sua união. 0 rei vivia transpassado pelo desgosto, e a rainha metia-se em impaciências das quais esse bom príncipe não era o único a se ressentir. Ela se queixava a todo o mundo pelo fato de não ter filhos. Não havia um cortesão a quem não pedisse ocultamente algum segredo para os ter e a quem não considerasse responsável pelos mal-sucedidos.

Os médicos não foram esquecidos, pois a rainha tinha paracom eles uma docilidade pouco comum. Eles não prescreviam uma droga que ela não fizesse preparar muito cuidadosamente para ter o prazer de atirá-la em seus rostos no instante em que fosse

1 Texto original de La Reine Fantasque fixado por PIERRE PERnaud. 0 texto foi transcrito da cópia manuscrita (Biblioteca pública e universitária de Neuchâtel, MsR 37, 14 folhas) por FrénéricS. Ergeldinger (SFM, Universidade de Neuchâtel). Tradução: Renato Moscateli. Revisão da tradução: Marcos A. Lopes. 
necessário tomá-la. Os dervixes ${ }^{2}$ tiveram sua vez. Foi necessário recorrer às novenas, aos votos e sobretudo às oferendas. Infelizes os servidores dos templos aonde Sua Majestade ia em peregrinação! Ela revirava tudo, e sob o pretexto de ir respirar um ar fecundo, não se omitiu até mesmo de colocar de pernas para 0 ar as celas dos monges. Ela carregava também suas relíquias e se vestia alternadamente com todos os seus diferentes trajes. Ora era um cordão branco, ora um cinto de couro, ora um capuz, ora um escapulário. Não havia nenhum tipo de mascarada monástica que sua devoção não aconselhasse, e como ela tinha um jovem ar de vivacidade que a mantinha charmosa sob todos os seus disfarces, não abandonava nenhum sem ter o cuidado de se fazer pintar com ele.

Enfim, à força de devoções tão bem feitas, à força de remédios tão sabiamente empregados, o céu e a terra atenderam aos votos da rainha. Ela ficou grávida no momento em que começava a se desesperar. Eu deixo adivinhar a alegria do rei e do povo, pois a da rainha ia, como todas as suas paixões, até a extravagância. Em seus transportes ela quebrava e rompia tudo; abraçava indiferentemente a todos que encontrava, homens, mulheres, cortesãos, valetes, correndo o risco de fazer sufocar quem se achasse em seu caminho. Ela não conhecia, dizia, arrebatamento igual ao de ter uma criança a quem pudesse açoitar bem à vontade em seus momentos de mau-humor.

Como a gravidez da rainha fora por muito tempo inutilmente esperada, ela se tornou um desses acontecimentos extraordinários dos quais todos querem ter a honra. Os médicos a atribuíam às suas drogas, os monges, às suas relíquias, o povo, às preces, e o rei, a seu amor. Cada um se interessava pela criança que devia nascer como se fosse sua, e todos faziam votos sinceros pelo feliz nascimento do príncipe. Pois se queria um, e o povo, os nobres e o rei convergiam seus desejos sobre esse ponto. A rainha achou muito ruim que se atrevessem a lhe prescrever a quem ela deveria dar à luz, e declarou que pretendia ter uma filha, acrescentando que lhe parecia bastante singular que alguém ousasse the disputar o direito de dispor de um bem que pertencia incontestavelmente apenas a ela.

Fênix quis em vão fazer-lhe ser razoável. Ela lhe disse claramente que isso não era assunto dele, e se trancou em seu gabinete para se emburrar, ocupação predileta na qual empregava regularmente ao menos seis meses do ano. Eu disse seis meses, mas não de uma só vez; havia também períodos de repouso que ela concedia a seu marido, entre os quais colocava intervalos próprios para aborrecê-lo.

0 rei compreendia muito bem que os caprichos de mãe não determinariam 0 sexo da criança, mas se desesperava que ela mostrasse assim suas excentricidades em

2 Sacerdotes muçulmanos (N. Do T.). 
espetáculo a toda a corte. Ele sacrificaria tudo no mundo para que a estima universal justificasse 0 amor que tinha por ela, e o estardalhaço que ela fez erroneamente nessa ocasião não foi a única loucura que o levou a acalentar a ridícula esperança de tornar sua mulher sensata.

Não sabendo mais a que santo se voltar, ele recorreu à fada Discreta, sua amiga e protetora de seu reino. Afada aconselhou-o a tomar as vias da brandura, isto é, pedir desculpas à rainha. "Aúnica meta" - disse-lhe ela -, "de todas as fantasias das mulheres édesorientar um pouco a arrogância masculina e acostumar os homens à obediência que lhes convêm. 0 melhor meio que vós tendes para curar as extravagâncias de vossa mulher éser extravagante comela. A partir do momento em que vós cessardes de contrariar seus caprichos, asseguro-vosde que la cessaráde os ter, e que ela nada mais esperapara se tornar sábia que vos ter tornado bem completamente louco. Fazei, portanto, as coisas de boa vontade e vos esforçai para ceder nessa circunstância a fim de obter tudo o que vós quereis em uma outra." 0 rei acreditou na fadae, para agir de acordo com a opinião dela quanto à rainha, ele a tomou à parte, disse-lhe bem baixo queestava aborrecido de haver se contrariado com ela, e que seesforçaria para compensáladali em diante pela complacência de humor que podia ter colocado em seus discursos ao se desentender rudemente comela.

Fantasiosa, que receava que apenas a complacência de Fênix não lhe compensasse de todo o ridículo desse caso, apressou-se em responder-lhe que sob essa desculpa irônica ela via ainda mais orgulho do que nas disputas precedentes, mas como as injustiças de um marido não autorizam em absoluto as de uma mulher, ela se apressou em ceder nessa ocasião como havia sempre feito. "Meu príncipe e meu esposo" - acrescentou ela bem alto -, "ordena-me dar à luz a um menino e eu conheço muito bem meu dever para deixar de obedecer. Não ignoro que quando Sua Majestade honra-me com sinais de seu carinho é menos por amor de mim que pelo de seu povo, cujo interesse não o ocupa menos à noite do que de dia. Eu devo imitar um tão nobre desinteresse, e vou pedir ao divã $\tilde{a}^{3}$ uma memória instrutiva sobre o número e o sexo das crianças que convêm à família real, memória importante à felicidade do Estado e pela qual toda rainha deve aprender a regular sua conduta durante a noite."

Este belo solilóquio foi escutado por todos os presentes com muita atenção, e eu vos deixo a pensar quantos estrondos de riso foram muito desajeitadamente abafados. "Ah!" - disse tristemente o rei afastando-se e balançado os ombros - "eu vejo bem que quando se tem uma mulher louca não se pode evitar ser um estúpido."

3 Conselho de notáveis que existia em certos governos orientais (N. Do T.). 
A fada Discreta, cujo sexo e nome contrastavam algumas vezes agradavelmente em seu caráter, achou essa querela tão alegre que resolveu se divertir até o fim. Ela disse publicamente ao rei que havia consultado os cometas que predizem os nascimentos dos príncipes, e que podia lhe responder que a criança que nasceria dele seria um menino. Porém, em segredo, assegurou à rainha que ela teria uma filha.

Esse aviso tornou Fantasiosa repentinamente tão sensata quanto ela tinha sido caprichosa até então. Foi com uma brandura e com uma complacência infinitas que ela tomou todas as medidas possíveis para desolar o rei e toda a corte. Ela se apressou em mandar preparar um enxoval dos mais soberbos, buscando fazê-lo tão próprio a um menino que ele se tornaria ridículo para uma menina. Foi preciso, neste desígnio, mudar muitas modas, mas tudo isso não lhe custava nada. Ela fez preparar um belo colar por encomenda, todo brilhante de pedrarias, e quis resolutamente que 0 rei nomeasse de antemão 0 governador ${ }^{4} \mathrm{e}$ preceptor do jovem príncipe.

Uma vez que ela estava segura de ter uma filha, não falava nada mais do que sobre seu filho, e não omitiu nenhuma das precauções inúteis que podiam fazer esquecer as que se teria devido tomar. Ela ria aos estrondos, ao se pentear, da postura assombrosa e estúpida que teriam os nobres e os magistrados que deveriam abrilhantar seu trabalho de parto com suapresença. "Parece-me" - dizia ela àfada -, "ver de um lado nosso venerável chanceler arvorar os grandes óculos para verificar o sexo da criança, e do outro, Sua sagrada Majestade baixar os olhos, e dizer balbuciando: “... eu acreditava... a fada me disse, contudo... senhores, não é erro meu", e outras máximas igualmente espirituosas reunidas pelos sábios da corte e logo levadas aos extremos das Índias."

Ela imaginava com um prazer maligno a desordem e a confusão que esse acontecimento maravilhoso ia causar em toda a assembléia. Ela antecipava as disputas, a agitação de todas as damas do palácio para reclamar, ajustar, conciliar nesse momento imprevisto os direitos de seus importantes cargos, e toda a corte em movimento por uma touca de bebê.

Foi também nessa ocasião que ela inventou o decente e espirituoso costume de fazer arengar pelos magistrados em toga o príncipe recém-nascido. Fênix quis lhe mostrar que era aviltar a magistratura desnecessariamente lançar uma cômica extravagância em todo o cerimonial da corte, ir com grande aparato expor Febo a um pequeno pirralho antes que ele pudesse entendê-lo, ou ao menos responder.

4 A palavra gouverneur, no original, designa neste caso o indivíduo que é encarregado da educação de um príncipe ou de certos jovens de famílias importantes (N. Do T.). 
"Eh, tanto melhor!" - respondeu vivamente a rainha -, "tanto melhor para vosso filho! Não seria muito feliz se todas as bobagens que eles terão a lhe dizer fossem esgotadas antes que ele as entendesse, e quereríeis vós que se guardasse para a idade da razão os discursos próprios a torná-lo louco? Por Deus, deixai-os arengá-lo bem à sua vontade, enquanto é certo que ele não os compreenda em nada e tenh a preocupação de menos. Vós deveis saber, aliás, que não se está sempre quite por tão pouco". Foi necessário aquiescer, e por ordem expressa de Sua Majestade os presidentes do senado e as academias começaram a compor, estudar, rasurar e folhear seu Vaumorière ${ }^{5}$ e seu Demóstenes ${ }^{6}$ para aprender a falar a um embrião.

Enfim, o momento crítico chegou. A rainha sentiu as primeiras dores com transportes de alegria que se vê pouco em semelhante ocasião. Ela se queixava com tão boa graça e chorava com um ar tão risonho que se acreditou que o maior de seus prazeres era o de dar à luz.

Logo se ouviu em todo o palácio um rumor apavorante. Uns correm a procurar 0 rei, outros os príncipes, outros os ministros, outros o senado, a maioria es mais apressados iam por ir e, rolando seu tonel como Diógenes, ${ }^{7}$ tinham em todo caso de se dar um ar atarefado. No empenho de reunir tantas pessoas necessárias, a última pessoa em quem se pensou foi na parteira, e o rei, cuja emoção o deixou fora de si, procurou por engano uma mulher sábia, e esta inadvertência excitou entre as damas do palácio risos imoderados que se juntaram ao bom humor da rainha, fazendo do parto o mais alegre de que jamais se ouvira falar.

Embora Fantasiosa tivesse guardado o melhor possível o segredo da fada, ele não havia deixado de escapar entre as mulheres de sua casa, e estas guardaram-no tão cuidadosamente elas mesmas que o boato levou mais de três dias para se espalhar por toda a cidade, de sorte que não passou muito tempo até que apenas o rei não soubesse de nada. Cada um estava então atento à cena que se preparava, o interesse público fornecendo um pretexto a todos os curiosos para se divertir às expensas da família real, os quais faziam uma festa de espiar a compostura de suas Majestades e de ver como com duas promessas contraditórias a fada poderia se safar do caso e conservar seu crédito.

5 PIERRE D'ORTIGUE, senhor de Vaumorière, gramático francês do século XVII, autor dos Discursos sobre todos os tipos de assuntos, com a arte de compô-los, publicados em 1687 (N. Do T.).

6 Célebre político e orador grego que viveu no século IV a.C., autor das Filípicas e do discurso Sobre a Coroa (N. Do T.).

7 Diógenes de SÍnope (413-327/4 a.C.), filósofo grego que viveu em Atenas, foi discípulo de Antístenes, o fundador da doutrina cínica. Viveu na mendicância, rejeitando as comodidades de seu tempo, por afirmar que elas não traziam nenhum bem, antes aumentando a dependência de que o homem devia se libertar. Segundo alguns autores, Diógenes teria residido durante muito tempo dentro de um tonel (N. Do T.). 
- Ora essa, meu senhor! - disse Jalamir ao druida interrompendo-se. - Concordai que somente compete a mim de vos impacientar com as regras. Pois vós sentis bem que aqui está o momento das digressões, dos retratos, e dessa multidão de belas coisas que todo autor, homem de espírito, não falta jamais de empregar propositadamente na parte mais interessante para divertir seus leitores.

- Como, por Deus - disse o druida -, imaginas tu que haveria tamanhos estúpidos para ler todo esse espírito aí? Aprende que se tem sempre de omiti-lo e que, a despeito do Senhor Autor, cobriu-se logo a sua ostentação com as folhas de seu livro. E tu, que fazes aqui o raciocinador, pensas que teus propósitos valem mais que o espírito dos outros, e que para evitar a imputação de uma estupidez basta dizer que caberia apenas a ti fazê-la? Verdadeiramente, seria preciso mais do que falar para prová-lo. E infelizmente, não tenho eu o recurso de virar as páginas.

- Consolai-vos - disse-lhe docemente Jalamir -, outros as virarão por vós se algum dia isto for escrito. Entretanto, considerai que eis toda a corte reunida no quarto da rainha, que é a mais bela ocasião que eu terei para vos descrever tantos ilustres originais e a única, talvez, que vós tereis para conhecê-los.

- Que Deus te ouça! - replicou alegremente o druida. - Eu não os conhecerei mais do que por suas ações. Fazei-os então agir se tua história tem necessidade deles e não diga nada sobre eles se forem inúteis. Não quero outros retratos além dos fatos.

- Uma vez que não há meio - disse Jalamir -, de alegrar meu relato com um pouco de metafísica, vou simplesmente retomar o fio. Mas contar por contarétedioso. Vós não sabeis quantas belas coisas perdereis! Ajudai-me, eu vos suplico, a me reencontrar, pois o essencial me arrebatou a tal ponto que eu não sei mais em que lugar estava do conto.

- Nessa rainha - disse o druida impaciente -, que tu tens tanta dificuldade de fazer dar à luz e com a qual tu me manténs há uma hora em trabalho.

- Oh, oh! - retomou Jalamir. - Credes vós que os filhos dos reis se põem como ovos de tordo? Vós ireis ver se não valia a pena perorar. A rainha, portanto, após muitos gritos e risos, acabou com o sofrimento dos curiosos e com a fada da intriga trazendo à luz uma menina e um menino mais bonitos que a lua e o sol, e que se pareciam tanto que se tinha dificuldade de distingui-los. Isto fez com que em sua infância se agradasse de vesti-los igualmente. Nesse momento tão desejado, o rei, saindo de sua majestade para se entregar à natureza, fez extravagâncias que em outros tempos não deixara fazer a rainha, e o prazer de ter filhos o tornava tão criança ele mesmo que correu a seu balcão gritando a plenos pulmões: "Meus amigos, regozijai-vos todos! Acaba de me nascer um filho, para 
vós um pai, ${ }^{8}$ e uma filha para minha mulher!" A rainha, que se encontrava pela primeira vez em sua vida em semelhante festa, não se apercebeu de toda a obra que tinha feito, $\mathrm{e}$ a fada, que conhecia seu espírito fantasioso, contentou-se em lhe anunciar inicialmente uma filha, em conformidade com o que ela tinha desejado. A rainha a fez trazer, e o que surpreendeu muito aos espectadores, ela a abraçou ternamente na verdade, mas com lágrimas nos olhos e com um ar de tristeza que se enquadrava mal com aquele que tinha até então. Eu já disse que ela amava sinceramente seu esposo. Ela havia sido tocada pela inquietude e pela comoção que tinha lido em seus olhares durante seus sofrimentos. Ela tinha feito, em um tempo na verdade singularmente escolhido, reflexões sobre a crueldade que havia em desolar um marido tão bom, e quando lhe apresentou sua filha, ela em nada mais pensava do que no desgosto que o rei sentiria por não ter um filho. Discreta, a quem o espírito de seu sexo e o dom da fadaria ensinavam a ler facilmente nos corações, compreendeu imediatamente o que se passava no da rainha, e não tendo mais razão para lhe disfarçar a verdade, fez trazer o jovem príncipe. A rainha, recuperando-se de sua surpresa, achou o expediente tão alegre que teve perigosas explosões de riso, no estado em que se encontrava. Ela se sentiu mal. Tiveram muita dificuldade para fazê-la recuperarse, e se a fada não respondesse por sua vida, a dor mais viva viria suceder aos transportes de alegria no coração do rei e sobre os semblantes dos cortesãos.

Mas eis o que houve de mais singular em toda essa aventura. 0 pesar sincero que tinha a rainha por haver atormentado seu marido a fez tomar uma afeição mais viva pelo jovem príncipe do que por sua irmã, e o rei, por seu lado, que adorava a rainha, demonstrou a mesma preferência pela filha que ela tinha desejado. As carícias indiretas que esses dois esposos únicos se faziam assim um ao outro se tornaram logo um gosto muito resoluto, e a rainha não podia mais passar sem o filho nem o rei sem a sua filha.

Esse duplo acontecimento trouxe uma grande alegria a todo o povo, e o acalmou ao menos por um tempo quanto ao pavor de faltarem senhores. Os espíritos fortes que tinham zombado das promessas da fada foram escarnecidos a seu turno. Mas eles não se deram por vencidos, dizendo que não concederiam mesmo à fada a infalibilidade da mentira nem às suas predições a virtude de tornar impossíveis as coisas que ela anunciava. Outros, baseados na predileção que começava a se declarar, exageravam na insolência até o ponto de sustentar que, dando um filho à rainha e uma filha ao rei, o acontecimento tinha de todo modo desmentido a profecia.

8 De acordo com a cultura política vigente no Antigo Regime, a qual foi bem expressa pelo célebre bispo BossuEt (16271704) na obra La politique tirée des propres paroles de l'Ecriture Sainte, o rei assumia seu título como 0 representante de Deus na Terra, exercendo um poder sagrado, paternal e absoluto sobre seus súditos (N. do T.). 
Enquanto se dispunha tudo para a pompa do batismo dos dois recém-nascidos, e 0 orgulho humano se preparava para brilhar humildemente nos altares dos deuses...

- Um momento! - interrompeu o druida. - Tu me confundes de uma maneira terrível. Ensina-me, eu te rogo, em qual lugar nós estamos. De início, para tornar a rainha grávida, tu a passeavasentre as relíquias e os capuchinhos. Depois disso tu nos fizestede repente passar às Índias. No presente tu vens me falar do batismo e depois dos altares dos deuses. Pelo grande Tharamis, ${ }^{9}$ eu não sei mais se nacerimônia que tu preparas nós vamos adorarJúpiter, a boa Virgem ou Maomé. Não que a mim, druida, importe muito que teus dois fedelhos sejam batizados ou circuncidados, mas aindaépreciso observar o costumeenão me expor a tomar um bispo pelo mufti ${ }^{10} \mathrm{e}$ o missal pelo Alcorão.

- Que grande infelicidade! - disse-lhe Jalamir. - Outros tão hábeis quanto vós se enganariam bem. Deus livre do mal a todos os prelados que têm serralhos e tomam pelo árabe o latim do breviário! Deus faça a paz entre todos os honestos delatores que seguem a intolerância do profeta de Meca, sempre prontos a massacrar santamente o gênero humano pela maior glória do Criador! Mas vós deveis vos recordar que nós estamos em um país de fadas onde não se envia pessoas ao inferno para o bem de sua alma, onde não se ousa observar o prepúcio das pessoas para as danar ou absolver, e onde a mitra e 0 turbante verde cobrem igualmente as cabeças sagradas para servir de sinal aos olhos dos sábios e de adorno aos dos estúpidos. Eu sei bem que as leis da geografia que regem todas as religiões do mundo querem que os dois recém-nascidos sejam muçulmanos, mas se circuncidam apenas os homens e eu tenho necessidade de que meus gêmeos sejam consagrados todos os dois. Assim, achai bom que eu os batize.

- Faz, faz - disse o druida. - Eis, palavra de sacerdote, a escolha mais bem motivada de que eu já ouvi falar em minha vida.

- A rainha, que se alegrava em perturbar toda a etiqueta, quis se levantar ao fim de seis dias e sair no sétimo sob o pretexto de que se sentia bem. De fato, ela alimentava seus filhos. Exemplo odioso do qual todas as mulheres the apresentaram muito fortemente as consequiências. Mas Fantasiosa, que temia os danos do leite derramado, sustentava que não havia tempo mais perdido para o prazer da vida do que aquele que vem depois da morte, e que o seio de uma mulher morta não murcha menos do que o de uma que amamenta, acrescentando em tom de mulher responsável que não há tão belo colo aos olhos de um marido que o de uma mãe que alimenta seus filhos. Essa intervenção dos maridos nos cuidados que eles observam tão pouco fez rir muito as damas, e a rainha,

9 Antigo deus celta (N. Do T.).

${ }^{10}$ Líder religioso muçulmano (N. Do T.). 
muito bela por sê-lo impunemente, pareceu-lhes desde então, apesar de seus caprichos, quase tão ridícula quanto seu esposo, que elas chamavam, por derrisão, o burguês de Vaugirard".

- Eu te vejo vir - disse no mesmo instante o druida -, tu gostarias de me dar insensivelmente o papel de Schah-Bahan e me fazer perguntar se há também um Vaugirard nas Índias, como uma Madri no bosque de Bologna, uma ópera em Paris, e um filósofo na corte. Mas prossiga tua rapsódia e não me estendas mais essas armadilhas, pois não sendo nem casado nem sultão, não vale a pena ser um estúpido.

- Enfim - disse Jalamir sem responder ao druida -, tudo estando pronto, o dia foi tomado para abrir as portas do céu aos dois recém-nascidos. A fada chegou bem cedo ao palácio e declarou aos augustos esposos que daria a cada um de seus filhos um presente digno de seu nascimento e de seu poder. "Eu quero" - disse ela -, "antes que a água mágica lhes subtraia à minha proteção, enriquecê-los de meus dons e dar-lhes nomes mais eficazes que os de todas as pessoas vis do calendário, pois eles experimentarão perfeições das quais eu terei o cuidado de lhes dotar ao mesmo tempo. Mas, como vós deveis conhecer melhor do que eu as qualidades que convêm à felicidade de vossa familia e de vosso povo, escolhei vós mesmos e fazei assim, em um só ato de vontade sobre cada um de vossos dois filhos, o que vinte anos de educação raramente fazem na juventude e o que a razão faz apenas em uma idade avançada."

No mesmo instante começou uma grande altercação entre os dois esposos. A rainha pretendia decidir sozinha, à suafantasia, o caráter de toda a sua familia, e o bom príncipe, que sentia toda a importância de uma semelhante escolha, não desejava abandoná-la ao capricho de uma mulher da qual ele adorava as loucuras sem as compartilhar. Fênix queria filhos que se tornassem um dia pessoas sensatas; Fantasiosa achava melhor ter filhos belos, e contanto que eles brilhassem aos seis anos, elase constrangia muito pouco de que fossem estúpidos aos trinta. Afada esforçou-se muito para colocar em acordo Suas Majestades. Logo, o caráter dos recémnascidos não foi mais do que o pretexto da disputa, e não era questão de se ter razão, mas de se trazer ume o outro à razão.

Enfim, Discreta imaginou um meio de ajustar tudo sem prejudicar ninguém, isto é, que cada um dispusesse à sua vontade da criança de seu sexo. 0 rei aprovou um expediente que proveria o essencial colocando a salvo dos bizarros desejos da rainha 0 herdeiro presuntivo da coroa, e vendo as duas crianças sobre os joel hos de sua governanta, ele se apressou em se apoderar do príncipe, não sem observar sua irmã com um olhar de

"Vaugirard era um pequeno vilarejo independente de Paris no século XVIII, mas que acabou sendo absorvido pela capital francesa em razão do crescimento desta (N. Do T.). 
comiseração. Mas Fantasiosa, tanto mais revoltada quanto menos razão tinha de o estar, correu como uma arrebatada à jovem princesa, tomando-a também em seus braços. "Vós vos unis todos" - disse ela -, "para me vencer, mas para que os caprichos do rei tornem, apesar dele mesmo, em proveito de um de seus filhos, eu declaro que peço para aquele que seguro tudo ao contrário do que ele pedirá para o outro. Escolhei agora" - disse ela ao rei com um ar de triunfo-, "e já que vós achais tantos atrativos em tudo dirigir, decidi com uma só palavra a sorte de vossa família inteira." A fada e o rei esforçaram-se em vão para dissuadi-la de uma resolução que colocava esse príncipe em um estranho embaraço, mas ela não quis desistir de forma alguma e disse que se felicitava muito de um expediente que faria jorrar sobre sua filha todo o mérito que o rei não saberia dar a seu filho. "Ah!" - disse esse príncipe ultrajado de despeito -, "Vós nunca tivestes por vossa filha mais que aversão e lhe provais na ocasião mais importante de sua vida. "Mas" - acrescentou ele em um transporte de cólera do qual não foi o senhor -, "para torná-la perfeita a despeito de vós, eu peço que esta criança aqui vos assemelhe". "Tanto melhor para vós e para ele" respondeu vivamente a rainha -, "mas eu serei vingada e vossa filha vos assemelhará." Assim que essas palavras foram lançadas de uma parte e de outra com uma impetuosidade sem igual, o rei, desesperado em seu aturdimento, quis muito retê-las, mas estava feito, e as duas crianças estavam dotadas sem volta das personalidades pedidas. 0 menino recebeu o nome de príncipe Capricho e a filha se chamou a princesa Razão, nome bizarro que ela ilustrou tão bem que nenhuma mulher ousou portá-lo desde então. Eis, então, o futuro sucessor ao trono ornado de todas as perfeições de uma bela mulher, e a princesa sua irmã destinada a possuir um dia todas as virtudes de um homem honesto e as qualidades de um bom rei. Uma partilha que não parecia das mais bem acertadas, mas em relação à qual não se podia mais voltar atrás. 0 agradável foi que o amor mútuo dos dois esposos, atuando nesse instante com toda a força que lhe davam sempre, mas às vezes muito tarde, as ocasiões essenciais, e a predileção não cessando de agir, cada um encontrou aquele de seus filhos que devia lhe parecer o menos agraciado dos dois, e pensou menos em felicitá-lo do que em lastimá-lo. 0 rei tomou sua filha em seus braços e a estreitou ternamente. "Infelizmente" - disse-lhe ele -, "de que te serviria a beleza de tua mãe sem o talento dela para a fazer valer? Tu serás muito sensata para fazer mudar a cabeça de alguém!" Fantasiosa, mais prudente sobre suas próprias verdades, não disse tudo o que pensava da sabedoria do futuro rei, mas era fácil de desconfiar, pelo ar triste com que 0 acariciava, que ela tinha no fundo do coração uma grande opinião de sua partilha. Entretanto, o rei, que a observava com uma espécie de confusão, fez-lhe algumas censuras a respeito do que havia se passado. "Eu sinto meus erros" - disse-lhe ela, "mas eles são 
obra vossa. Nossos filhos teriam valido muito mais do que nós, e vós sois a causa de que eles não farão mais do que nos assemelhar. "Ao menos" - disse-lhe ela em seguida, saltando sobre o pescoço de seu marido -, "eu estou certa de que eles se amarão tanto quanto é possível". Fênix, emocionado com o que havia de terno nesse arrebatamento, consolou-se com essa reflexão que tinha tão freqüentemente ocasião de fazer, ou seja, que a bondade natural e um coração sensível bastam para tudo reparar.

- Eu adivinho tão bem todo o resto - disse o druida a Jalamir interrompendo-0 -, que terminarei o conto para ti. Teu príncipe Capricho fará virar a cabeça de todo 0 mundo e será muito bem imitador de sua mãe para não ser seu tormento. Ele perturbará o reino querendo reformá-lo. Para tornar seus súditos felizes, ele os deixará em desespero, tomando seus próprios erros pelos dos outros, e injusto por ter sido imprudente, o pesar por suas faltas o fará cometê-las de novo. Como a sabedoria não o conduzirá jamais, o bem que ele quiser fazer aumentará o mal que ele terá feito. Em uma palavra, ainda que no fundo ele seja bom, sensível e generoso, suas próprias virtudes o levarão ao erro e apenas seu aturdimento, unido a seu poder, o fará mais odiado do que o teria feito uma maldade bem pensada. De outro lado, tua princesa Razão, nova heroína do país das fadas, tornarse-á um prodígio de sabedoria e de prudência, e sem ter adoradores se fará a tal ponto amar pelo povo que cada um fará votos de ser governado por ela. Sua boa conduta vantajosa a todo o mundo e a ela mesma não causará problemas a não ser a seu irmão, cujos vícios opor-se-ão sem cessar às virtudes dela, e a quem a prevenção pública dará todos os defeitos que ela não terá, mesmo quando ele próprio não os tiver. Será questão de inverter a ordem da sucessão ao trono, de submeter 0 cetro $^{12}$ à roca ${ }^{13} \mathrm{e}$ a fortuna à razão. Os doutores exporão com ênfase as conseqüências de um tal exemplo e provarão que vale mais que o povo obedeça cegamente aos fanáticos que o azar pode lhes dar por mestres do que escolher ele mesmo chefes sensatos; que ainda que se interditasse a um louco 0 governo de seus próprios bens, é bom deixar-lhe a suprema disposição de nossos bens e vidas; que o mais insensato dos homens é ainda preferível à mais sábia das mulheres; $\mathrm{e}$ que se o macho ou o primogênito fosse um macaco ou um lobo, seria necessário, em boa política, que uma heroína ou um anjo que nasceu depois obedecesse às vontades dele. Objeções e réplicas da parte dos sediciosos, nas quais Deus sabe como se verá brilhar a

\footnotetext{
${ }^{12}$ A palavra marotte, no original, designa o cetro composto de um bastão encimado por uma cabeça grotesca coberta por um capuz com guizos, o qual é considerado o símbolo da loucura e serve de atributo aos bufões da corte (N. Do T.).

${ }^{13}$ A palavra quenouille, no original, refere-se simbolicamente à condição feminina e aos trabalhos reservados às mulheres (N. Do T.).
} 
sofística eloqüência: pois eu te conheço, é sobretudo ao maldizer o que faz que tua bile se exale com volúpia, e tua amarga franqueza parece se regozijar com a maldade dos homens pelo prazer que experimenta ao reprová-la.

- Ora essa, pai druida, como vós ides! - disse Jalamir todo surpreso. - Que fluxo de palavras! De onde diabos tomastes vós tão belas tiradas? Em toda a vossa vida, nunca pregastes tão bem assim no bosque sagrado, embora não tenhais falado mais que a verdade. Se eu deixasse em vossas mãos, vós transformaríeis logo um conto de fadas em um tratado de política, e ele seria achado algum dia nos gabinetes dos príncipes Barba Azul ou Pele de Asno ${ }^{14}$ no lugar de Maquiavel. Mas não vos esforceis tanto para adivinhar o final de meu conto. Para vos mostrar que o desfecho não negligencia o necessário, eu vou, em poucas palavras, expedir um não tão sábio quanto o vosso, mas talvez tão natural e, com toda a certeza, mais imprevisto.

Vós sabereis então que os dois filhos gêmeos eram, como já observei, tão parecidos de figura e, além disso, vestidos iguais, que o rei, crendo ter tomado seu filho, segurava sua filha entre seus braços no momento da influência, e que a rainha, enganada pela escolha de seu marido, tendo tomado também seu filho por sua filha, a fada aproveitouse desse erro para dotar as duas crianças da maneira que lhes conviesse melhor. Capricho foi então o nome da princesa, e Razão o do príncipe seu irmão, e a despeito das bizarrices da rainha, tudo se achou na ordem natural. Alçado ao trono após a morte do rei, Razão fez muito de bem e pouco barulho. Procurando antes cumprir seus deveres que adquirir reputação, ele não fez guerra aos estrangeiros nem violência a seus súditos, e recebeu mais bendizeres do que elogios. Todos os projetos feitos no reinado precedente foram executados no dele, e ao passar da dominação do pai para a do filho, o povo foi duas vezes feliz crendo não ter mudado de senhor. A princesa Capricho, após ter feito perder a vida ou a razão a multidões de amantes ternos e gentis, casou-se enfim com um rei vizinho que ela preferiu porque ele portava o mais longo bigode saltava melhor em um pésó. Quanto a Fantasiosa, morreu de uma indigestão de ensopado de pés de perdiz que ela desejou comer, antes de meter no leito, onde o rei cansou-se de esperá-la, em uma noite na qual, à força de provocações, havia-o incitado a vir se deitar com ela.

Fim

\footnotetext{
${ }^{14}$ Ambos são personagens literários. Barba Azul era um nobre que teve muitas esposas, as quais ele assassinou uma após a outra. Pele de Asno, por sua vez, era uma jovem princesa que, após fugir de seu palácio e tentar disfarçar suas origens aristocráticas, terminou por casar-se com um rei (N. Do T.).
} 
O conto filosófico La Reine Fantasque, de autoria do escritor suíço Jean-Jacques Rousseau (1712-1778), foi publicado originalmente em 1756, mas não se tornou tão célebre quanto algumas de suas outras obras. 0 texto é pouco citado en tre os comentadores que se dedicaram ao estudo do pensamento rousseauniano, e, ao que parece, não existe, ainda, nenhuma tradução publicada em português. Assim, mostra-se oportuno divulgar a obra, possibilitando aos leitores brasileiros conhecê-la. A importância de publicar esse conto, porém, não reside somente no fato de que seja pouco conhecido. Uma vez que seu tema principal é a realeza, esse "conto de fadas", como define o narrador, constitui uma valiosa fonte para o estudo das idéias de Rousseau sobre a monarquia. Em conjunto com outras de suas obras, o texto contém reflexões importantes sobre as instituições políticas vigentes no século XVIII, instituições predominantemente aristocráticas que tinham na monarquia absolutista seu ponto central (N. Do T.).

Recebido em outubro de 2004. 